\title{
DIAMOND FACIES PYROXENITES FROM THE BENI BOUSERA PERIDOTITE MASSIF AND IMPLICATIONS FOR THE ORIGIN OF ECLOGITE XENOLITHS.
}

\author{
D.G. Pearson ${ }^{(1)}$; G.R. Davies ${ }^{(2)}$ and P.H. Nixon ${ }^{(3)}$.
}

(1) Department of Terrestrial Magnestism, Carnegie Institution of Washington, Washington D.C. 20015, U.S.A.; (2) Dept. of Geological Sciences, University of Michigan, Ann Arbor, Michigan, U.S.A.; (3) Dept. of Earth Sciences, University of Leeds, Leeds LS29JT, U.K.

The Beni Bousera peridotite massif contains mineralogically diverse pyroxenite layers, many of which are lithologically analogous to xenoliths erupted by deeply-derived kimberlite/alkali basalt magmatism. Two garnet clinopyroxenites have been found to contain graphite as octahedral aggregates and other forms of cubic symmetry which are interpreted as graphitized diamonds (Pearson et al., 1989). This interpretation is supported by the occurrence of cubo-octahedral faceted CPX and GT inclusions within the octahedra. The pyroxenite suite shows major and compatible trace element fractionation trends indicating crystallisation from magmatic liquids fractionating OPX, CPX, GT. Combined with the mineralogical zonation observed in many of the layers the chemical variation indicates pyroxenite crystallisation as wall-rock cumulates from magma flowing through the peridotites. However, incompatible elements vary widely in abundance and show no correlation with major element fractionation indices. The majority of pyroxenites are more LREE-depleted than the peridotites, the former having $(\mathrm{Ce} / \mathrm{Sm})_{\mathrm{n}}$ ranging from 0.016 to 0.91 . These data preclude derivation of the pyroxenites from either the host peridotites or a single mantlederived magma and require a chemically heterogeneous source.

Positive and negative $\mathrm{Eu}$ anomalies in the pyroxenites (Eu/Eu ${ }^{*}=0.7$ to 2.4 , indicate the parent liquids were derived from low pressure precursors which had experienced plagioclase fractionation.

Oxygen isotope analyses of CPX from the pyroxenite suite show a wide variation in $\delta^{180}$ values $(+4.9$ to $+9.3 \%)$, in contrast with the restricted range shown by the host peridotites $\left(\delta^{18} \circ_{\mathrm{CPX}}=+5.3\right.$ to $+6.0 \%$ ). Coexisting $\mathrm{CPX}-\mathrm{GT}$ and $\mathrm{CPX}-\mathrm{OPX}$ mineral pairs from the pyroxenites are in high temperature isotopic equilibrium suggesting that the 0 -isotope variation is not the result of recent disequilibrium/metasomatic processes. There is no correlation between $\delta^{18} \mathrm{O}$ and fractionation indices such as $\mathrm{mg}$ no. implying that the oxygen isotope variation is not due to high temperature igneous processes and that the pyroxenites are not derived from normal mantle peridotite sources. The oxygen isotope data indicates derivation of the pyroxenites from precursors that have experienced crustal, low temperature hydrothermal alteration at high water rock ratios (Pearson et al., 1991).

Acid-washed CPX separates from the pyroxenites show extreme Nd and $\mathrm{Sr}$ isotopic diversity $\left(143_{\mathrm{Nd}} / 144 \mathrm{Nd}=0.5139-0.5122,{ }^{87} \mathrm{Sr} /{ }^{86} \mathrm{Sr}=\right.$ $0.7023-0.7110$, Fig. 1) but many show decoupled parent/daughter ratios implying they have suffered a recent partial melting event $(<200 \mathrm{Ma})$. Mixing of the pyroxenites with late stage, crustal fluids/melts during the emplacement of the massif cannot explain the diverse scatter of the pyroxenite CPX on an Sr-Nd isotope diagram (Figure 1). The data may be explained by crystallisation of the pyroxenites from melts of subducted oceanic crustal precursors which experienced variable degrees hydrothermal alteration (which acted to increase ${ }^{87} \mathrm{Sr} /{ }^{86} \mathrm{Sr}$ ) and incorporated variable amounts of sediment during subduction. Incorporation of the sediment produced unradiogenic $143_{\mathrm{Nd}} / 144 \mathrm{Nd}$ and more radiogenic $87 \mathrm{Sr} / 86 \mathrm{Sr}$. Pyroxenite $\mathrm{CPX}$ show scattered trends of $\delta^{180}$ vs ${ }^{87} \mathrm{Sr} /{ }^{86} \mathrm{Sr}$ (which ranges up to $0.7110)$. Samples with the highest $\delta^{18} 0$ values also have high ${ }^{87} \mathrm{Sr} /{ }^{86} \mathrm{Sr}(0.7078-0.7085)$. The relatively diffuse $\mathrm{Sr}-0$ isotope correlation is to be expected if the pyroxenites are derived from 
melts of different portions of subducted oceanic crust that experienced alteration at different water/rock ratios.

The high $207 \mathrm{pb} / 206 \mathrm{pb}$ of some of the pyroxenite $\mathrm{CPX}$ are consistent with subducted sediment incorporation in some of the parental magmas. Furthermore, the $\mathrm{Pb}$ data constrain some of the pyroxenites to be relatively young $(<200 \mathrm{Ma})$ which is consistent with the relatively unradiogenic $143 \mathrm{Nd} / 144 \mathrm{Nd}$ of the graphite-bearing pyroxenites despite their very high $147 \mathrm{Sm} / 144 \mathrm{Nd}$ (up to 1.7 ). Some pyroxenites with unradiogenic initial $87 \mathrm{Sr} / 86 \mathrm{Sr}(0.7025)$ and very radiogenic $143^{\mathrm{Nd}} / 144 \mathrm{Nd}(0.5139)$ may be up to $1 \mathrm{Ga}$ old; this age is consistent with Os isotope data for the Beni Bousera pyroxenites (Luck and Allegre, 1990).

Derivation of the pyroxenites from hydrothermally altered, subducted oceanic crust over a period of possibly $1 \mathrm{Ga}$ is capable explaining their diverse radiogenic and stable isotope systematics and their incompatible element heterogeneity. Recent, small degree melting of some of the more "evolved" pyroxenites due to diapiric upwelling during emplacement of the peridotite massif from the diamond stability field enhanced their LREE depletion and disrupted isotope-trace element relationships.

Graphite from the garnet clinopyroxenites has low $\delta^{13} \mathrm{C}$ values $(-16$ to $-27.6 \%) . \mathrm{CO}_{2}$ released by high temperature step-heating of a $\mathrm{CPX}$ separate also yielded significant amounts of isotopically light carbon $\left(\delta^{13} \mathrm{C}=-22 \%\right)$ indicating, along with field relationships, that the isotopically light carbon in the graphitic pyroxenites is inherited from the precursor diamonds and may have originated from subduction of either kerogenous carbon or isotopically light hydrothermal carbonate veins in altered oceanic crust.

The Beni Bousera garnet pyroxenites are mineralogically and chemically comparable to eclogite xenoliths from kimberlites, some showing evidence of having contained the high diamond contents found in several diamondiferous eclogites (eg. Robinson et al., 1984). The current dispute whether some eclogites from kimberlites represent subducted metamorphosed oceanic crust or high pressure, mantle derived cumulates may be resolved if some eclogites crystallised from melts (producing igneous textures) derived from subducted oceanic lithosphere (giving crustal isotopic signatures). The subducted crustal signature of the Beni Bousera pyroxenites and the isotopically light $\delta^{13} \mathrm{C}$ values of the diamond pseudomorphs they contain is further support for a subducted origin for some E-type diamonds.

\section{References}

Luck, J.M. and Allègre, C.J. (1990) Osmium isotopes and mantle processes. Terra Abstacts, 2, 134-135.

Pearson, D.G., Davies, G.R., Nixon, P.H. and Milledge, H.J. Graphitised diamonds from a peridotite massif in Morocco and implications for anomalous diamond occurrences. Nature, 338, 60-62.

Pearson, D.G., Davies, G.R., Nixon, P.H., Greenwood, P.B. and Mattey, D.P. (1991) Oxygen isotope evidence for the origin of pyroxenites in the Beni Bousera peridotite massif, North Morocco: Derivation from subducted oceanic lithosphere. Earth and Planetary Science Letters, 102, 289-301.

Robinson, D.N., Gurney, J.J. and Shee, S.R. (1984) Diamond eclogite and graphite eclogite xenoliths from orapa, Botswana. In J. Kornprobst, Ed., Kimberlites II: The mantle and crust-mantle relationships, p11-24, Elsevier, Amsterdam. 


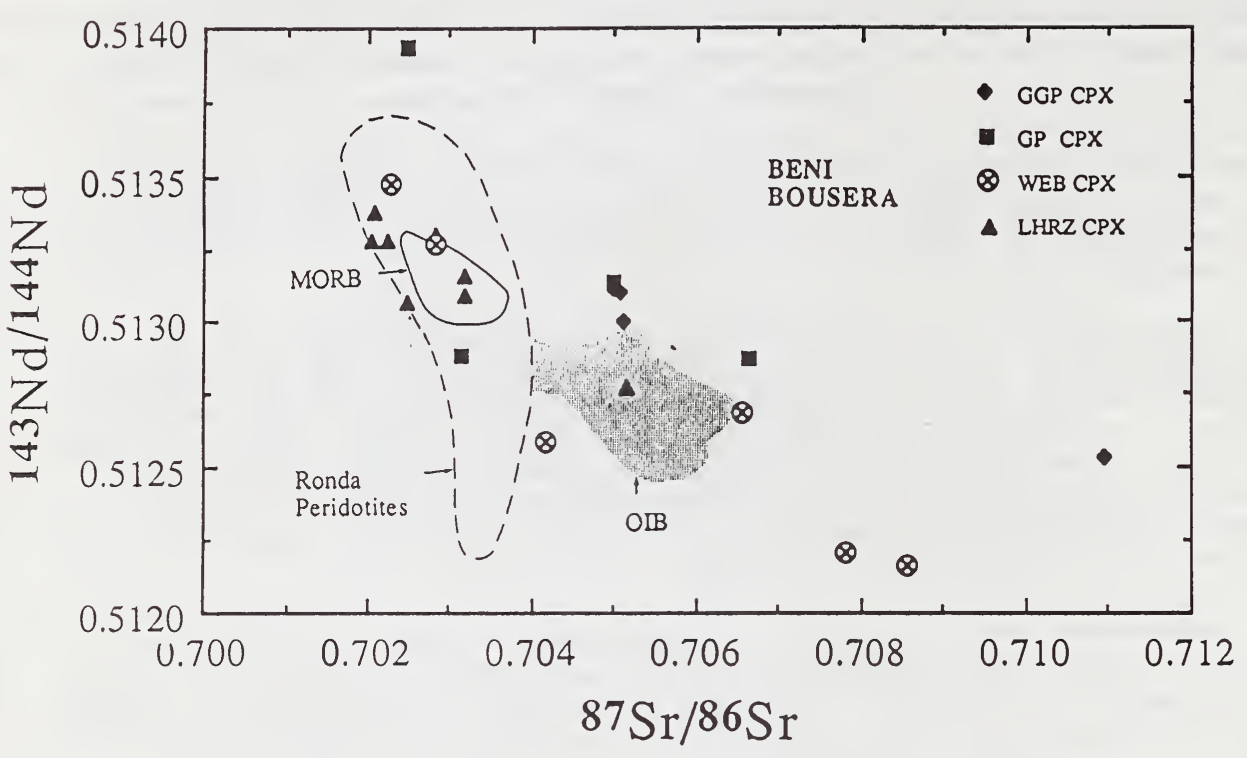

Figure 1: Sr-Nd isotope plot of CPX from Beni Bousera pyroxenites and peridotites compared to MORB, OIB and Ronda peridotites. GGP =graphite garnet clinopyroxenites, GP = garnet clinopyroxenites, $\mathrm{WEB}=$ websterites, LHRZ = spinel lherzolites. 